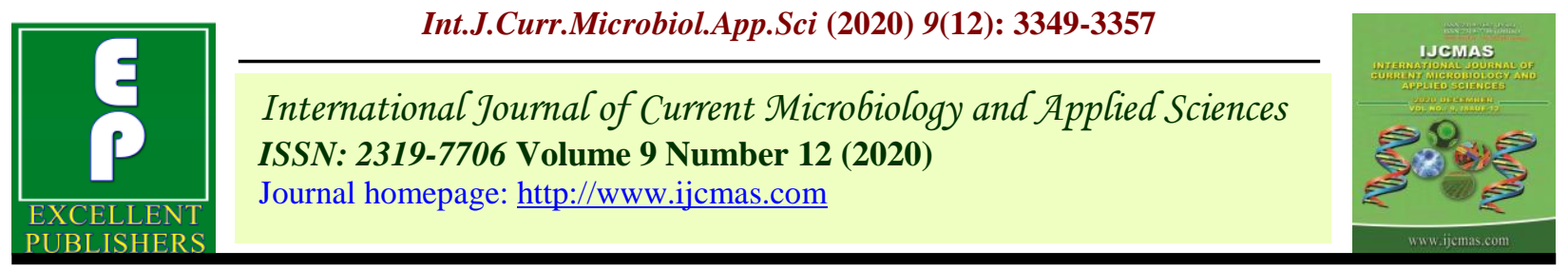

Original Research Article

https://doi.org/10.20546/ijcmas.2020.912.399

\title{
Response of Nanoherbicide Application on Striga Management in Sugarcane
}

\author{
E. Iyarin Thanka Mahil ${ }^{1 *}$, B. N. Aravinda Kumar ${ }^{1}$, Ramesh Babu ${ }^{1}$, P. Jones \\ Nirmalnath $^{2}$ and N. S. Hebsur ${ }^{3}$
}

${ }^{1}$ Department of Agronomy, ${ }^{2}$ Department of Agricultural Microbiology, ${ }^{3}$ Department of Soil

Science, College of Agriculture, Dharwad, University of Agricultural Sciences, Dharwad - 580 005, Karnataka, India

*Corresponding author

\section{A B S T R A C T}

\section{Keywords}

Nanocomposite laoded with atrazine, Sugarcane, Striga emergence, Striga density, Striga control index

Article Info

Accepted:

28 November 2020 Available Online: 10 December 2020

\begin{abstract}
A pot experiment was conducted to test the bioefficacy of nanocomposite based slow release formulation of atrazine herbicide to control Striga asiatica in sugarcane during 2018-2019 in polyhouse, University of Agricultural Sciences, Dharwad. The experiment was laid out in a randomized block design and replicated thrice with seven treatments viz., nanocomposite loaded with atrazine (NCA) @ $1.25 \mathrm{~kg}$ a.i./ha applied at 80 DAP, 95 DAP and 110 DAP, atrazine @ $1.25 \mathrm{~kg}$ a.i./ha applied at 80 DAP, 95 DAP and 100 DAP and Weedy check. Observations on first days to Striga emergence, Striga density, Striga dry weight, Striga control index and Striga seed capsules per plant were recorded. NCA applied at 95 DAP delayed the emergence by 30 days than weedy check. Moreover at 165 DAP, lower Striga density $\left(2.330 .2 \mathrm{~m}^{-2}\right)$, Striga dry weight $\left(0.86 \mathrm{~g}^{2} .2 \mathrm{~m}^{-2}\right)$, Striga height $(1.32 \mathrm{~cm})$, Striga control index $(100 \%)$ and number of Striga capsules $\left(0\right.$ plant $\left.^{-1}\right)$ recorded with the application of NCA @ $1.25 \mathrm{~kg}$ a.i./ha at 95 DAP.
\end{abstract}

\section{Introduction}

Striga is a parasitic weed that invades farmlands and infests cereals. It damages crop plants by attaching itself to their roots and feeding on their nutrients, causing the crops to be stunted, discolored and twisted (Anon., 2006). In the Striga presence, crop plants will have limited space to develop their shoots, which amounts to reduced photosynthesis in them. Since, Striga is established directly over the vascular system of the host plant, it drains out water and nutrients from host resulting in yield losses from 15 to 75 per cent depending on the extent of infestation (Oswald and Ransom, 2001). Recently, In North Karnataka, lot of Striga incidence is noticed on sugarcane farmer's fields resulting in considerable yield losses. Shift in cultivation from traditional sorghum and maize to sugarcane on account of higher monetary benefit is also one of the major reason for Striga infestation in sugarcane fields. Generally in the field of sugarcane, 
farmers are practicing hand weeding as well as repeated application of herbicides for the control of Stirga. However, the root portion of Striga weed will remain in the soil while the Striga weed is being pulled, with the possibility of more flushes coming from the single root after seven days of hand weeding.

The repeated application of herbicides leads into deterioration of soil health. Hence, there is a need of long persistence systemic herbicides for the effective management of Striga in sugarcane. In this regard, there is a possible to developing the nanocomposite based pre-emergence herbicide (atrazine) assures season long weed control. The present study was, therefore, planned and conducted to know the effect of nanoherbicide application on the management of Striga in sugarcane under green house condition.

\section{Materials and Methods}

Graphene oxide based slow release formulation of nanocomposite loaded with atrazine herbicide was used for the striga management. Graphene oxide is synthesized by Hummer's method (Hummers and Offeman, 1958). To test the bioefficacy of nanocomposite loaded atrazine herbicide (NCA) a pot Culture experiment was conducted during 2018-19 in polyhouse, University of Agricultural Sciences, Dharwad, which is situated at $15^{\circ} 29^{\prime} \mathrm{N}$ latitude, $74^{0} 59^{\prime} \mathrm{E}$ longitudes and at an altitude of $689 \mathrm{~m}$ above mean sea level. Dharwad falls under Northern Transition Zone (Zone-8) of Karnataka which lies between Hilly zone and Northern Dry Zone. The soil for pot culture experiment was collected from farmer's field, Yaragatti village of Saundatti taluk, Belgaum district, which was infested by Striga. The experiment was laid out in Complete Randomized Block Design (CRD) and replicated thrice with seven treatments viz., NCA @ $1.25 \mathrm{~kg}$ a.i./ha applied at 80 DAP, 95 DAP and 110 DAP, atrazine @ $1.25 \mathrm{~kg}$ a.i./ha applied at 80 DAP, 95 DAP and 100 DAP and Weedy check. Two eye budded setts were prepared from a 10 month old sugarcane crop and planted by pressing in the pot. Observations were recorded for first days to Striga emergence, Striga density, Striga height, Striga dry weight, Striga capsules number per plant and Striga control index on 95, 110, 125 and 165 DAP.

The original data were transformed by using square root $\sqrt{x+0.5}$ and analyzed statistically. Fischer's method of analysis of variance was applied for statistical analysis and interpretation of data was done as given by Gomez and Gomez (1984). The level of significance used in ' $F$ ' and ' $t$ ' test was $p=$ 0.05. Critical difference was calculated wherever ' $F$ ' test was significant. The mean values of treatments subjected to Duncan's Multiple Range Test (DMRT) using the error mean sum of squares and degrees of freedom values under M-STAT-C program.

\section{Results and Discussion}

\section{Emergence pattern of Striga}

The mean number of days for the first Striga emergence ranged from 108 to 140 DAP. However, NCA @ $1.25 \mathrm{~kg}$ a.i./ha applied at 95 DAP delayed the Striga emergence by 30 days than weedy check. Besides, NCA @ $1.25 \mathrm{~kg}$ a.i./ha applied at 80 DAP and atrazine @ $1.25 \mathrm{~kg}$ a.i./ha applied at 95 DAP delayed the Striga emergence by 14 and 13 days respectively over weedy check (Table 1).

\section{Number of Striga per pot $\left(0.2 \mathrm{~m}^{2}\right)$}

Number of Striga per pot differed significantly due to application of herbicides and the data are furnished in Table 2. 
At 95 DAP, there was no emergence of Striga in all the treatments. At 110 DAP, NCA @ $1.25 \mathrm{~kg}$ a.i./ha applied at 95 DAP and NCA @ $1.25 \mathrm{~kg}$ a.i./ha applied at $80 \mathrm{DAP}$ recorded no emergence of Striga. Whereas, the Striga appeared in other treatments viz., NCA @ $1.25 \mathrm{~kg}$ a.i./ha applied at $110 \mathrm{DAP}$, atrazine @ $1.25 \mathrm{~kg}$ a.i./ha applied at $80 \mathrm{DAP}, 95 \mathrm{DAP}$ and 110 DAP and weedy check and was ranged from 0.33 to 3.33 pot $^{-1}\left(0.2 \mathrm{~m}^{2}\right)$. At 125 DAP, NCA @ $1.25 \mathrm{~kg}$ a.i./ha applied at 95 DAP recorded no appearance of Striga which was significantly different over rest of the treatments. It was followed by NCA @ $1.25 \mathrm{~kg}$ a.i./ha applied at 80 DAP (2.0) and atrazine @ $1.25 \mathrm{~kg}$ a.i./ha applied at 95 DAP (2.33). Whereas, Striga density was higher with weedy check (11.0). Similar trend was noticed in 165 DAP also. The Striga density was significantly lower (2.33) with NCA @ $1.25 \mathrm{~kg}$ a.i./ha applied at 95 DAP. This was followed by application of NCA @ $1.25 \mathrm{~kg}$ a.i./ha at 80 DAP (4.33) and atrazine @ 1.25 $\mathrm{kg}$ a.i./ha at 95 DAP (6.77). Whereas, weedy check recorded significantly higher Striga density of 25 .

\section{Height of Striga $(\mathrm{cm})$}

Height of Striga in sugarcane differed significantly due to application of herbicides and the data are furnished in Table 3.

The height of Striga was recorded only in those treatments which showed Striga emergence. At 110 DAP, weedy check recorded significantly taller Striga plants $(3.24 \mathrm{~cm})$ compared to other treatments. At 125 DAP, there was no emergence of Striga in the treatment receiving NCA @ $1.25 \mathrm{~kg}$ a.i./ha applied at 95 DAP. Treatment receiving NCA @ $1.25 \mathrm{~kg}$ a.i./ha applied at 80 DAP (1.86) recorded shorter Striga plants and was on par with NCA @ $1.25 \mathrm{~kg}$ a.i./ha applied at 80 DAP (1.86), NCA @ $1.25 \mathrm{~kg}$ a.i./ha applied at 110 DAP (2.95), atrazine @
$1.25 \mathrm{~kg}$ a.i./ha applied at 110 DAP (3.22) and atrazine @ $1.25 \mathrm{~kg}$ a.i./ha applied at 95 DAP (3.28), respectively. Weedy check recorded significantly taller Striga plants (3.24) compared to other treatments. Within the treatments, at 165 DAP application of NCA @ $1.25 \mathrm{~kg}$ a.i./ha at $95 \mathrm{DAP}$ recorded shorter Striga plants (1.32) which was on par with NCA @ $1.25 \mathrm{~kg}$ a.i./ha applied at 80 DAP (2.85), NCA @ $1.25 \mathrm{~kg}$ a.i./ha applied at 110 DAP (6.62) and atrazine @ $1.25 \mathrm{~kg}$ a.i./ha applied at 95 DAP (7.13), respectively. Meanwhile, significantly taller Striga plants (60.56) were noticed with weedy check.

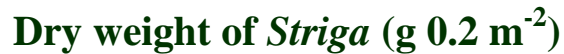

Dry weight of Striga in sugarcane differed significantly due to application of herbicides and the data are furnished in the Table 4.

The dry weight of Striga was recorded only in those treatments which showed Striga emergence. At 110 DAP, there was no appearance of Striga with the treatments of NCA @ $1.25 \mathrm{~kg}$ a.i./ha applied at 95 DAP, NCA @ $1.25 \mathrm{~kg}$ a.i./ha applied at 80 DAP and atrazine @1.25 kg a.i./ha applied at 95 DAP. Weedy check recorded significantly higher dry weight of Striga (0.03) compared to other treatments.

At 125 DAP, NCA @ $1.25 \mathrm{~kg}$ a.i./ha applied at 80 DAP recorded lower value of Striga dry weight (0.03) and which was followed by atrazine @ $1.25 \mathrm{~kg}$ a.i./ha applied at 95 DAP (0.07) and NCA @ $1.25 \mathrm{~kg}$ a.i./ha applied at 110 DAP (0.09), respectively. As expected the dry weight of Striga was significantly higher (0.45) with weedy check. At 165 DAP, significantly lower Striga dry weight (0.86) was found with the treatment NCA @ $1.25 \mathrm{~kg}$ a.i./ha applied at 95 DAP compared to other treatments and it was on par with other herbicide applied treatments viz., NCA @ $1.25 \mathrm{~kg}$ a.i./ha applied at 80 DAP (1.02), 
atrazine @ $1.25 \mathrm{~kg}$ a.i./ha applied at 95 DAP (1.45) and NCA @ $1.25 \mathrm{~kg}$ a.i./ha applied at 110 DAP (1.62), respectively. Whereas, significantly a higher Striga dry weight was recorded in the weedy check (28.56).

\section{Striga control index (\%)}

Striga control index denotes the efficiency of applied herbicide or treatment effect in reducing the dry weight of weeds. It was computed by utilizing the dry weight data of Striga at 110, 125 and 165 DAP and the data pertaining to Striga control index presented in Table 4. Since there was no Striga emergence at 95 DAP, the striga control index was computed at 125 and 165 DAP. NCA @ 1.25 $\mathrm{kg}$ a.i./ha applied at 95 DAP recorded higher Striga control index at both 125 and 165 DAP (100 and 96.99, respectively). This was followed by NCA @ $1.25 \mathrm{~kg}$ a.i./ha applied at 80 DAP (93.33 and 96.43) and atrazine @ $1.25 \mathrm{~kg}$ a.i./ha applied at 95 DAP (84.44 and 94.92) (Table 5).

\section{Number of Striga seed capsules per plant}

The number of Striga seed capsules per plant as influenced by application of herbicides is furnished in Table 6. Significant differences were recorded in number of seed capsules per Striga among the treatments. However, NCA (a) $1.25 \mathrm{~kg}$ a.i./ha applied at $95 \mathrm{DAP}$ and NCA @ $1.25 \mathrm{~kg}$ a.i./ha applied at 110 DAP did not result in formation of seed capsules. The number of seed capsules per plant rangesd from 0 to 8 with the herbicide applied treatments. As expected the weedy check recorded significantly higher number of Striga seed capsules per plant (69).

Application of nanocomposite loaded atrazine herbicide delayed the Striga emergence by 15 days more than commercial atrazine herbicide. This might be achieved by slow releasing behavior of nanocomposite. The results are in conformity with the findings of Hussein et al., 2005 who found that nanocomposite loaded 2, 4-D herbicide which was incapsulated with zinc-alumium layered double hydroxide provides the sustained release of active ingredient upto $24 \mathrm{hrs}$, while the commercial formulation has taken only 60 mins.

In addition, the Striga germination got delays when herbicide applied at 95 DAP over the other time of application viz., 80 DAP and 110 DAP. Application of herbicide at 85 DAP was early and the bioefficacy of herbicide had reduced by the time of Striga emerged. Findings are also in line with the report of Saunshi, 2018 who stated that application of pre-emergent herbicide at 90 DAP was more effective in reducing Striga emergence compared to application at 60 DAP. Although nanoherbicde applied at early (i.e., at 85 DAP) which retain the bioefficacy until the Striga emergence and effectively attack the emerged Striga. Application of herbicide at 110 DAP was too late, before that Striga got emerged out and started to deplete the nutrients from the sugarcane root and which kills only the late emerged Striga.

Delaying of Striga emergence resulted into the reduction of Striga population. Striga density in both the experimental site was ranged between 4 to $16 \mathrm{~m}^{-2}$ in the herbicide treated plot and $49 \mathrm{~m}^{-2}$ in weedy check, respectively. Macopiyo et al (2010) categorized the level of Striga infestation as low ( 1 to $4 \mathrm{~m}^{-2}$ ), medium (4 to $9 \mathrm{~m}^{-2}$ ) and severe $\left(>9 \mathrm{~m}^{-2}\right)$. According to him, infestation level was low in nonoherbicide applied plot at 95 DAP. Whereas, herbicide applied at later stage i.e. 110 DAP, weed free check and weedy check categorized as severe level of Striga infestation and the leftout treatment considered as medium level of Striga infestation. 
Table.1 Emergence pattern of Striga as influenced by application of nanoherbicide under greenhouse condition

\begin{tabular}{|l|c|c|c|}
\hline \multicolumn{1}{|c|}{ Treatment } & \multicolumn{3}{c|}{ Emergence pattern of Striga } \\
(DAP)
\end{tabular}

1,2 and 3 represent first, second and third flush of Striga respectively

DAP- Days After Planting; NCA - Nanocomposite loaded with atrazine; NA - Not analysed

Table.2 Number of Striga per pot $\left(0.2 \mathrm{~m}^{2}\right)$ as influenced by application of nanoherbicide under greenhouse condition

\begin{tabular}{|c|c|c|c|c|}
\hline Treatment & 95 DAP & 110 DAP & 125 DAP & 165 DAP \\
\hline $\begin{array}{l}T_{1} \text { - NCA @ } 1.25 \mathrm{~kg} \text { a.i./ha applied at } 80 \\
\text { DAP }\end{array}$ & $* 0.71(0)$ & $0.71(0)^{\mathrm{a}}$ & $1.58(2.00)^{\mathrm{b}}$ & $2.20(4.33)^{b}$ \\
\hline $\begin{array}{l}T_{2} \text { - NCA @ } 1.25 \mathrm{~kg} \text { a.i./ha applied at } \\
95 \text { DAP }\end{array}$ & $0.71(0)$ & $0.71(0)^{\mathrm{a}}$ & $0.71(0)^{\mathrm{a}}$ & $1.68(2.33)^{\mathrm{a}}$ \\
\hline $\begin{array}{l}T_{3} \text { - NCA @ } 1.25 \mathrm{~kg} \text { a.i./ha applied at } \\
110 \text { DAP }\end{array}$ & $0.71(0)$ & $1.78(2.67)^{\mathrm{b}}$ & $1.87(3.00)^{\mathrm{c}}$ & $2.74(7.00)^{\mathrm{c}}$ \\
\hline $\begin{array}{l}\mathrm{T}_{4} \text { - Atrazine @ } 1.25 \mathrm{~kg} \text { a.i./ha applied } \\
\text { at } 80 \text { DAP }\end{array}$ & $0.71(0)$ & $1.35(1.33)^{\mathrm{ab}}$ & $2.27(4.67)^{d}$ & $3.49(11.67)^{c}$ \\
\hline $\begin{array}{l}T_{5} \text { - Atrazine @ } 1.25 \mathrm{~kg} \text { a.i./ha applied } \\
\text { at } 95 \text { DAP }\end{array}$ & $0.71(0)$ & $0.91(0.33)^{\mathrm{a}}$ & $1.68(2.33)^{b c}$ & $2.68(6.67)^{\mathrm{c}}$ \\
\hline $\begin{array}{l}T_{6} \text { - Atrazine @ } 1.25 \mathrm{~kg} \text { a.i./ha applied } \\
\text { at } 110 \text { DAP }\end{array}$ & $0.71(0)$ & $1.96(3.33)^{\mathrm{b}}$ & $2.12(3.99)^{\mathrm{d}}$ & $3.63(12.67)$ \\
\hline$T_{7}$ - Weedy check & $0.71(0)$ & $1.68(2.33)^{\mathrm{ab}}$ & $3.39(11.00)^{\mathrm{e}}$ & $5.05(25.00)^{c}$ \\
\hline S.Em. \pm & \multirow[t]{2}{*}{ NA } & 0.04 & 0.26 & 0.30 \\
\hline $\mathrm{CD}(\mathrm{p}=0.05)$ & & 0.12 & 0.78 & 0.91 \\
\hline
\end{tabular}

Means followed by the same letter(s) within a coloumn are not significantly differed by DMRT ( $\mathrm{p}=0.05)$; *Transformed values $[\sqrt{ }(\mathrm{X}+0.5)]$, Figures in the parantheses indicate original values; DAP- Days After Planting; NCA - Nanocomposite loaded with atrazine; NA - Not analysed 
Table.3 Height of Striga $(\mathrm{cm})$ as influenced by the application of nanoherbicide under greenhouse condition

\begin{tabular}{|c|c|c|c|c|}
\hline Treatment & 95 DAP & 110 DAP & 125 DAP & 165 DAP \\
\hline $\begin{array}{l}T_{1} \text { - NCA @ } 1.25 \mathrm{~kg} \text { a.i./ha applied } \\
\text { at } 80 \text { DAP }\end{array}$ & $* 0.71(0)$ & $0.71(0)^{\mathrm{a}}$ & $1.54(1.86)^{b}$ & $1.83(2.85)^{\mathrm{a}}$ \\
\hline $\begin{array}{l}T_{2} \text { - NCA @ } 1.25 \mathrm{~kg} \text { a.i./ha applied } \\
\text { at } 95 \text { DAP }\end{array}$ & $0.71(0)$ & $0.71(0)^{\mathrm{a}}$ & $0.71(0)^{\mathrm{a}}$ & $1.35(1.32)^{\mathrm{a}}$ \\
\hline $\begin{array}{l}T_{3} \text { - NCA @ } 1.25 \mathrm{~kg} \text { a.i./ha applied } \\
\text { at } 110 \text { DAP }\end{array}$ & $0.71(0)$ & $1.73(2.49)^{\mathrm{d}}$ & $1.86(2.95)^{\mathrm{b}}$ & $2.67(6.62)^{\mathrm{a}}$ \\
\hline $\begin{array}{l}T_{4} \text { - Atrazine @ } 1.25 \mathrm{~kg} \text { a.i./ha applied } \\
\text { at } 80 \text { DAP }\end{array}$ & $0.71(0)$ & $1.56(1.93)^{\mathrm{c}}$ & $2.44(5.44)^{\mathrm{c}}$ & $4.35(18.39)^{b}$ \\
\hline $\begin{array}{l}T_{5} \text { - Atrazine @ } 1.25 \mathrm{~kg} \text { a.i./ha applied } \\
\text { at } 95 \text { DAP }\end{array}$ & $0.71(0)$ & $1.19(0.92)^{b}$ & $1.94(3.28)^{b}$ & $2.76(7.13)^{\mathrm{a}}$ \\
\hline $\begin{array}{l}T_{6} \text { - Atrazine @ } 1.25 \mathrm{~kg} \text { a.i./ha applied } \\
\text { at } 110 \text { DAP }\end{array}$ & $0.71(0)$ & $1.69(2.35)^{\mathrm{cd}}$ & $1.93(3.22)^{b}$ & $3.87(14.50)^{b}$ \\
\hline $\mathbf{T}_{7}$ - Weedy check & $0.71(0)$ & $1.93(3.24)^{\mathrm{e}}$ & $3.63(12.71)$ & $7.81(60.56)^{\mathrm{c}}$ \\
\hline S.Em. \pm & \multirow[t]{2}{*}{ NA } & 0.05 & 0.61 & 2.41 \\
\hline $\mathrm{CD}(\mathrm{p}=0.05)$ & & 0.14 & 0.43 & 1.86 \\
\hline
\end{tabular}

Means followed by the same letter(s) within a coloumn are not significantly differed by DMRT ( $\mathrm{p}=0.05)$; *Transformed values $[\sqrt{ }(\mathrm{X}+0.5)]$, Figures in the parantheses indicate original values; DAP- Days After Planting;

NCA - Nanocomposite loaded with atrazine; NA - Not analysed

Table.4 Dry weight of Striga $\left(\mathrm{g} / 0.2 \mathrm{~m}^{2}\right)$ as influenced by the application of nanoherbicide under greenhouse condition

\begin{tabular}{|c|c|c|c|c|}
\hline Treatment & 95 DAP & 110 DAP & 125 DAP & 165 DAP \\
\hline $\begin{array}{l}T_{1} \text { - NCA @ } 1.25 \mathrm{~kg} \text { a.i./ha applied at } \\
80 \text { DAP }\end{array}$ & $* 0.71(0)$ & $0.71(0)^{\mathrm{a}}$ & $0.73(0.03)^{b}$ & $1.23(1.02)^{\mathrm{ab}}$ \\
\hline $\begin{array}{l}T_{2} \text { - NCA @ } 1.25 \mathrm{~kg} \text { a.i./ha applied at } \\
95 \text { DAP }\end{array}$ & $0.71(0)$ & $0.71(0)^{\mathrm{a}}$ & $0.71(0)^{\mathrm{a}}$ & $1.17(0.86)^{\mathrm{a}}$ \\
\hline $\begin{array}{l}T_{3} \text { - NCA @ } 1.25 \mathrm{~kg} \text { a.i./ha applied at } \\
110 \text { DAP }\end{array}$ & $0.71(0)$ & $0.72(0.02)^{c}$ & $0.77(0.09)^{\mathrm{c}}$ & $1.46(1.62)^{\mathrm{ab}}$ \\
\hline $\begin{array}{l}T_{4} \text { - Atrazine @ } 1.25 \mathrm{~kg} \text { a.i./ha applied at } \\
80 \text { DAP }\end{array}$ & $0.71(0)$ & $0.71(0.01)^{b}$ & $0.80(0.14)^{d}$ & $1.68(2.31)^{b}$ \\
\hline $\begin{array}{l}T_{5} \text { - Atrazine @ } 1.25 \mathrm{~kg} \text { a.i./ha applied at } \\
\text { 95 DAP }\end{array}$ & $0.71(0)$ & $0.71(0)^{\mathrm{a}}$ & $0.75(0.07)^{\mathrm{c}}$ & $1.40(1.45)^{\mathrm{ab}}$ \\
\hline $\begin{array}{l}T_{6}-\text { Atrazine @ } 1.25 \mathrm{~kg} \text { a.i./ha applied at } \\
110 \text { DAP }\end{array}$ & $0.71(0)$ & $0.73(0.03)^{d}$ & $0.79(0.12)^{d}$ & $2.10(3.93)^{\mathrm{c}}$ \\
\hline $\mathbf{T}_{7}$ - Weedy check & $0.71(0)$ & $0.73(0.03)^{\mathrm{d}}$ & $0.97(0.45)^{\mathrm{e}}$ & $5.39(28.56)^{\mathrm{d}}$ \\
\hline S.Em. \pm & \multirow[t]{2}{*}{ NA } & 0.0004 & 0.005 & 0.41 \\
\hline $\mathrm{CD}(\mathrm{p}=0.05)$ & & 0.0012 & 0.017 & 1.27 \\
\hline
\end{tabular}

Means followed by the same letter(s) within a coloumn are not significantly differed by DMRT ( $\mathrm{p}=0.05)$;

*Transformed values $[\sqrt{ }(\mathrm{X}+0.5)]$, Figures in the parantheses indicate original values; DAP- Days After Planting;

NCA - Nanocomposite loaded with atrazine; NA - Not analysed 
Table.5 Striga control index (\%) as influenced by the application of nanoherbicide under greenhouse condition

\begin{tabular}{|l|c|c|}
\hline Treatment & 125 DAP & 165 DAP \\
\hline$T_{1}$ - NCA @ 1.25 kg a.i./ha applied at 80 DAP & 93.33 & 96.43 \\
\hline$T_{2}$ - NCA @ 1.25 kg a.i./ha applied at 95 DAP & 100.00 & 96.99 \\
\hline$T_{3}$ - NCA @ 1.25 kg a.i./ha applied at 110 DAP & 80.00 & 94.33 \\
\hline$T_{4}$ - Atrazine @ 1.25 kg a.i./ha applied at 80 DAP & 68.89 & 91.91 \\
\hline$T_{5}$ - Atrazine @ 1.25 kg a.i./ha applied at 95 DAP & 84.44 & 94.92 \\
\hline$T_{6}$ - Atrazine @ 1.25 kg a.i./ha applied at 110 DAP & 73.33 & 86.24 \\
\hline$T_{7}$ - Weedy check & 0.00 & 0.00 \\
\hline
\end{tabular}

DAP- Days After Planting; NCA - Nanocomposite loaded with atrazine

Table.6 Number of Striga seed capsules per plant as influenced by the application of nanoherbicide under greenhouse condition

\begin{tabular}{|c|c|}
\hline Treatment & At harvest \\
\hline T1 - NCA @ $1.25 \mathrm{~kg}$ a.i./ha applied at 80 DAP & $1.22(1)^{\mathrm{a}}$ \\
\hline$T_{2}$ - NCA @ $1.25 \mathrm{~kg}$ a.i./ha applied at 95 DAP & $0.71(0)^{\mathrm{a}}$ \\
\hline$T_{3}$ - NCA@1.25 kg a.i./ha applied at 110 DAP & $0.71(0)^{\mathrm{a}}$ \\
\hline $\mathrm{T}_{4}$ - Atrazine @ $1.25 \mathrm{~kg}$ a.i./ha applied at 80 DAP & $2.92(8)^{\mathrm{c}}$ \\
\hline $\mathrm{T}_{5}$ - Atrazine @ $1.25 \mathrm{~kg}$ a.i./ha applied at 95 DAP & $1.22(1)^{\mathrm{a}}$ \\
\hline $\mathrm{T}_{6}$ - Atrazine @ $1.25 \mathrm{~kg}$ a.i./ha applied at $110 \mathrm{DAP}$ & $2.35(5)^{b}$ \\
\hline $\mathbf{T}_{7}$ - Weedy check & $8.34(69)^{\mathrm{d}}$ \\
\hline S.Em. \pm & 0.64 \\
\hline $\mathrm{CD}(\mathrm{p}=\mathbf{0 . 0 5})$ & 1.94 \\
\hline
\end{tabular}

Means followed by the same letter(s) within a column are not significantly differed by DMRT $(\mathrm{p}=0.05)$

*Transformed values $[\sqrt{ }(\mathrm{X}+0.5)]$, Figures in the parantheses indicate original values

DAP- Days After Planting; NCA - Nanocomposite loaded with atrazine

Nanoherbicide applied pot shows lower Striga density than the pot received commercial herbicide. It might be attributed by large specific surface area of nanoherbicide which increases the affinity to target. Application of herbicide at 80 DAP recorded higher Striga density than herbicide applied at 95 DAP and 110 DAP.

The results in particular suggest that application of herbicide at 80 DAP has not been able to control the emergence of Striga; the application at this seems to be getting very early. The parasite has been probably still responding to the breaking mechanisms of dormancy and encountering its underground growth phase, during which it continues to develop haustoria to attach to the host crop. Delayed Striga appearance may also be the effect of inadequate seed conditioning at the beginning of the season. However, herbicides applied at 95 DAP recorded lower Striga density which may have coincided with the formation of haustoria and delayed the Striga emergence. The present results corroborate with the findings of Odhiambo and Ransom (1993) who reported that Dicamba applied at 6 WAP reduced Striga population than applied at 4 WAP in maize. 
Days to first Striga emergence is strongly correlated with the dry weight of Striga. Among the treatments application of nanoherbicide recorded lower dry weight of Striga than the application of commercial formulation of herbicide and weedy check. The present findings are in agreement with Sousa et al 2018 who stated that root and shoot growth and dry weight of B. Pilosa weed got reduced more effectively with the application of atrazine loaded nanocapsules than the commercial formulation. In another research study Kumar and Chinnamuthu (2017) also reported the same result of low amount of dry biomass of weed with the application of nanoencapsulated herbicide formulation $(5 \mathrm{~g} / \mathrm{m} 2)$ than the commercial formulation of herbicide treatment $(19 \mathrm{~g} / \mathrm{m} 2)$. This may be achieved by the modified release of atrazine by the nanocomposite with the better uptake through root (Pereira et al., 2014).

Capsule production of Striga related with the Striga density and dry weight. The obtained average number of seed capsules per plant ranged between 1 to 8 in the herbicide treated plot and around 40 to 55 in the weedy check plot. Plot supplied with nanoherbicide produced significantly fewer capsules per plant than other commercial herbicide treated plot. Because of lower population of Striga biomass number of seed capsules proportionally get reduced (Kudra Abdul, 2011; Rodenburg et al., 2006). In addition, the capsule formation of Striga plants most associated with above ground Striga biomass than below ground suppression (Carsky et al 1994).

In conclusion the NCA applied at 95 DAP delayed the emergence by 30 days than weedy check. Moreover at 165 DAP, lower Striga density (2.33 $\left.0.2 \mathrm{~m}^{-2}\right)$, Striga dry weight (0.86 g $\left.0.2 \mathrm{~m}^{-2}\right)$, Striga height $(1.32 \mathrm{~cm})$, Striga control index (100\%) and number of Striga capsules $\left(\begin{array}{lll}0 & \text { plant }^{-1}\end{array}\right)$ recorded with the application of NCA @ $1.25 \mathrm{~kg}$ a.i./ha at 95 DAP. Hence nanocomposite based atrazine can be used in effective management of Striga.

\section{References}

Anonymous, 2006, Empowering African farmers to eradicate Striga from maize croplands. AATF. Nairobi, Kenya. p. 17.

Carsky, R. J., Singh, L. and Ndikawa, R., 1994, Suppression of Striga hermonthica on sorghum using a cowpea intercrop. Exp. Agric., 30: 349 - 358.

Gomez, K. A. and Gomez, A. A., 1984, Statistical Procedures for Agricultural Research, $2^{\text {nd }} E d n$. John Wiley and Sons, New York, USA, p 680.

Hummers, W. S., Offeman, R. E., 1958, Preparation of graphitic oxide. J. Am. Chem. Soc., 80(6): 1339.

Hussein, M. Z., Yahaya, A. H., Zainal, Z. and Kian, L. H., 2005, Nanocompositebased controlled release formulation of an herbicide, 2,4- dichlorophenoxyacetate encapsulated in zincaluminiumlayered double hydroxide. Sci. Tech. Adv. Mat., 6: 956-962.

Kudra Abdul, 2011, Influence of soil fertility management on striga reproduction and grain yield of sorghum in semiarid areas of Tanzania. Ph.D thesis submitted to University of Nairobi, p.69

Kumar, P. and Chinnamuthu, 2017, Assembly of Nanoencapsulated Pendimethalin Herbicide using Solvent Evaporation Method for Season Long Weed Control under Irrigated Ecosystem, Int. J. Pure App. Biosci. 5(1): 349-357.

MacOpiyo, L., Vitale, J. and Sanders, J., 2010, An ex-ante assessment of a Striga control programme in East Africa. Kilimo Trust, pp. 136. 
Odhiambo, G. D. and Ransom, J. K., 1993, Effect of dicamba on the control of Striga hermonthica in maize in western Kenya. Afr. Crop Sci. J., 1 (2): 105110.

Pereira, A. E. S., Grillo, R., Mello, N. F. S., Rosa, A. H. and Fraceto, L. F., 2014, Application of poly(epsiloncaprolactone) nanoparticles containing atrazine herbicide as an alternative technique to control weeds and reduce damage to the environment. J. Hazard. Mater., 268: 207-215.

Rodenburg, J., Bastiaans, L., Kropff, M. J. and Van Ast, A., 2006, Effects of host plant genotype and seedbank density on
Striga reproduction. Weed Res., 46: 251-263.

Saunshi Sudheendra, 2018, Striga Management in Sugarcane (Saccharum officinarum L.) on participatory research, Ph.D thesis submitted to University of Agricultural Sciences, Dharwad. p.386

Sousa, G. F. M., Gomes, D. G., Campos, E. V. R., Oliveira, J. L., Fraceto, L.F., Stolf-Moreira, R. and Oliveira, H.C., 2018, Post-Emergence Herbicidal Activity of Nanoatrazine Against Susceptible Weeds. Front. Environ. Sci., 6:12.

\section{How to cite this article:}

Iyarin Thanka Mahil, E., B. N. Aravinda Kumar, Ramesh Babu, P. Jones Nirmalnath and Hebsur, N. S. 2020. Response of Nanoherbicide Application on Striga Management in Sugarcane. Int.J.Curr.Microbiol.App.Sci. 9(12): 3349-3357.

doi: https://doi.org/10.20546/ijcmas.2020.912.399 